\title{
The Role of Power Distance in the Relationship between Employee Motivation and Organizational Commitment: A Study on Education Sector of Pakistan
}

\author{
Muhammad Saadat Din ${ }^{1}$, Dr. Mohsin Bashir ${ }^{2}$, Khaliq Ur Rehman Cheema ${ }^{3}$, \\ Sehrish Saba Zafar ${ }^{4}$ \\ ${ }^{I}$ MS Scholar at Department of Business Administration, Govt. College University Faisalabad \\ ${ }^{2}$ Assistant Professor at Government College University Faisalabad \\ ${ }^{3} \mathrm{PhD}$ Scholar at School of Business and Economics, University of Management and Technology Lahore \\ ${ }^{4}$ MS Scholar at Department of Business Administration, Govt. College University Faisalabad
}

\begin{abstract}
The tenacity of this study was to reconnoitre the connotation amongst employee's motivation and organizational commitment in the education sector of Pakistan and the moderating role of power distance in this relationship. The organizational commitment encompasses three components namely: affective, continuance and normative commitment. The results on the base of randomly selected sample of 300 respondents, gathered from public and private sector universities of Pakistan with the response rate of 86 percent, explained that relationship between employee motivation and organizational commitment is positive. Based on Hierarchical Multiple Regression Model, the results also concluded that power distance moderates the relationship between employee motivation and organizational commitment components (affective, normative and continuance commitment) in education sector of Pakistan.
\end{abstract}

Keywords: Affective Commitment; Continuance Commitment; Employees Motivation; Hierarchical Linear Model; Normative Commitment; Power Distance.

\section{Introduction}

For human beings, personality development in education is essential. Education has significant role in changing individual behavior and attitude. In today's effervescent changing environment, people have to learn for survival. New discoveries \& innovations require humans to prepare themselves to fulfill future challenges. Instrument that brings out changes in community, society and nation is the education (Shami, 1999). For economic development of a nation higher education has an important role. Innovation and ideas can generate through research that helps for development of human resources.

Pakistan is passing through transition phase of development of education and is under economic threats due to global recession. Along with internal factors, external factors can also effect employee's affiliation to organization known as commitment. In Pakistan, there is change in employee's values due to global factors. So due to these changes there exists two values, one is national value and other is work related value. National values traditionally coherent with culture and work related values represent modern reflecting economy. Organizations can achieve greater HR satisfaction who response to these changes. There is not proper use of HR practices in Pakistan. Even many years of independence has passed, employees in Pakistani organizations are demotivated \& dissatisfied. So, there is a need to strengthen motivation level and steps must be taken to transform disappointment in to satisfaction that is an efficient forecaster of organizational commitment (Warsi et al., 2009).

The numbers of Pakistani universities has been increasing since previous 10 years for fulfilling the quality of research and education standard. Huge amounts on infrastructure and human development has been spendby the government of Pakistan. Higher education commission of Pakistan (HEC) plays a major role in providing universities up to date technology, facilities for research, highly qualified staff are recruited, announcement of scholarships, pay on distinctive research and funds for projects etc. Creating commitment between faculty members of the institutions or universities, these dimensions (affective, continuance \& normative) are obviously looked nice but what reality is there, analysed in this paper. Purpose of this study was to ascertain power distance role in relationship between employee's motivation and organizational commitment (affective, continuance $\&$ normative) in education sector of Pakistan. This study has the potential to prove the relationship of employee's motivation with organizational commitment types such as relationship with affective, continuance and normative commitment in education sector specifically in universities of Pakistan. 


\subsection{Research Objectives}

1.1.1 To identify relationship between employee's motivation and affective commitment.

1.1.2 To determine relationship between employee's motivation and continuance commitment.

1.1.3 To identify relationship between employee's motivation and normative commitment.

1.1.4 To determine power distance role in the relationship between employee's motivation and affective commitment.

1.1.5 To determine power distance role in the relationship between employee's motivation and continuance commitment.

1.1.6 To investigate power distance role in the relationship between employee's motivation and normative commitment.

Figure 1.1 Conceptual Framework

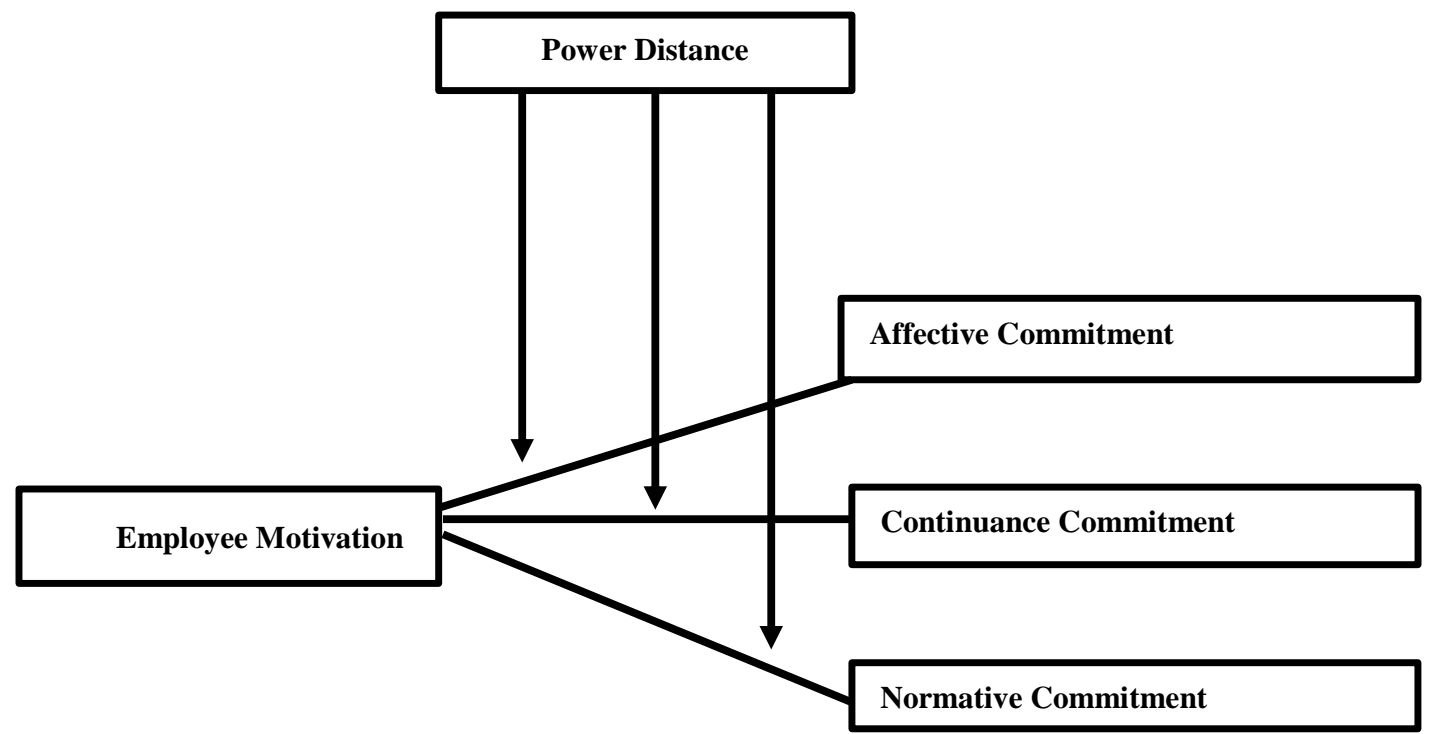

\section{Literature Review}

To build employee's commitment, employers are striving to compensate with motivational factors, as a result they gain competitive advantage in building employee's commitment to the organization. These types of activities have supportive effect on spirit at job \& employee's productivity. It also been realized by most of the employers that motivated and committed workforce who are efficient, productive and dedicated to an organization are key to success. To gain employee's commitment, employers have to seek proactive thinking in energizing employee's to move towards organizational commitment.

Most of the organizational goals are fulfilled by employees work and managers need competent and creative staff. Even though certain factors which are considered as most important have contribution toward the creativity and performance at job. Job performance does consist of four items: task understanding, environment, ability \& motivation (Mitchell, 1982).

\subsection{Motivation}

Motivation is derived from Latin word motus, verb form movere that is taken in the meaning of move, alter, influence, and stimulate. Rainey (1993) explained that motivation is the degree to which a person is spin or stimulates to act. Mitchell (1982), states motivation as "the goad to action". Whereas according to scholars "it is psychological processes that cause the arousal, direction, and continuance of individual's behavior towards goal achievement" (Greenberg \& Baron, 2003; Robbins \& Judge, 2008).Snell (1999) advocated that motivation is everything. Without it, the most talented individuals are unable to show up their capacity. They perform above their expected intelligence level and abilities with motivation.

Motivation is intentional and directional (Nel et al., 2001). Intentional motivation is the person's choice for continuance of that particular action. Directional motivation designates that there are some forces having objectives to attaining particular goal. A person who is motivated constantly, conscious of fact that particular target must accomplished and even in the face of diversity, he or she continuously efforts to achieve that goal. Motivation comprise of two types, intrinsic motivation and extrinsic motivation.

Intrinsic motivation is a type of motivation that comes from inside of an individual. This type of motivation is generated through pleasure or satisfaction that individual gets on completing a task or even 
working on that task. Intrinsic motivation is defined as the doing of an activity for its inherent satisfaction rather than for some separable consequence (Ryan \& Deci, 2000).Extrinsic motivation means performing an activity in a pressure, tension, or anxiety to achieve the desire results (Lindenberg, 2001). Hennessey and Amabile (2005) analysed that extrinsic motivation is the motivation to do some activity to make sure that some external goal is attained or that some external imposed constraint is met. This type of motivation can be seen in everyday life. For example employees go to work to receive salary or student that is obliged to go to university because their parents make them go.

\subsection{Employee's Motivation}

The most important part in the company success and development is the employee's motivation. To maximizing overall performance of the company, it is important for the employers to understand which factors motivate the employee's more and how much they are satisfied with their job. For any organization, employee's motivation is major issue. All employers want their people to perform to the best of their abilities, thus, by providing all the necessary resources and a better working environment to keep employee's motivated. But it remains a difficult factor to manage because employee's targets and aspirations sometime do not match what their employers provide to them (Lather \& Jain, 2005). This is challenging for a company because all employees have not equal thinking and are motivated by different things. Employees can be motivated through different ways like pay, promotion, and praise. Similarly, employees can also motivate themselves by seeking work environment where individual goals, needs and wants can be achieved.

Employee's motivation argued by Robbins (as cited in Ramlall, 2004), "the willingness to exert high levels of effort toward organizational goals, conditioned by the effort's ability to satisfy some individual need." It is considered as the most important concept in the field of organizational behaviour and human resource management. It is the key to make organization more effective and helps to predict a performance and job satisfaction (Graford, 2011; Lather \& Jain, 2005). The arguments made by (Anderfuhren et al., 2010) that motivated employees, are the cornerstone of any organization and, Smith (1994) says that employee motivation helps organization to survive. (Nel et al., 2001) mentioned that motivated employees possess an awareness of organizational goals, which are achieved in particular ways, and they direct their efforts towards achieving such goals. Motivation also plays an effective role in organizational commitment.

\subsection{Organizational Commitment}

Organizational commitment is a stronger attachment of employee with an organization, in which he is performing his duties and how much he is contributing in the achievement of organization's objectives (Kinicki \& Kreitner, 2003). Rayton (2006) specify commitment as feelings of an individual loyalty with that particular organization. When employees are committed to their organization they pursue a huge loyalty to organization, become more defensive about organization when that particular organization feels a kind of risk.

Kinicki and Kreitner (2003) analysed that organizational commitment refers to the degree that an employee identifies with the company where he is working and is committed to the objectives of the company. Organizational commitment is the factor that measures the willingness of employee's to stay within an organization in future. Sometimes, it indicates employee's belief to mission and objectives of an organization, their readiness in expanding struggle in goals and is intended to carry on work there. Organizational commitment comprise of three types: affective, continuance and normative commitment. Affective commitment is defined as "an employee's desire to be emotionally attached to the identification with and involvement in the organization" (Allen \& Meyer, 1990; Meyer \& Allen, 1997). Continuance commitment is defined as "the employees' awareness or recognition of the benefits of continuing to remain in the organization versus the perceived cost of leaving the organization" (Allen \& Meyer, 1990; Meyer \& Allen, 1991). Normative commitment is defined as "a consequence of an employee's feeling of obligation to stay inthe organization based on one's personal norms and values" (Allen \& Meyer, 1990; Meyer \& Allen, 1991)

\subsection{Power Distance}

Amongst the four cultural dimensions define by Geert Hofstede (2001), power distance is one of the national culture dimension. It indicates the facts, which a society accepts that in institutions and organizations power is distributed unequally. Societies having high power distance are generally more hierarchical and bureaucratic while societies with low power distance are more market-oriented and less bureaucratic, and have a more open form of communication (Bialas, 2009; Shane, 1994). According to Hofstede (2001) high power distance may lead to a very autocratic, controlling type of leadership whereas a low power distance may give rise to a more democratic approach. Cultures with high power distance tend to have authoritarian decision making mechanisms whereas cultures with low power distance tend to have more participatory decision making mechanisms (Rodrigues, 1998). 


\section{Hypothesis \\ 3.1 The Relationship between Employee's Motivation and Organizational Commitment}

In psychology of organization, commitment and motivation studies have usually evolved independently to some extent (Meyer et al., 2004). Commitment is a motivation component and, has importance that it gains better understanding of two processes themselves and behaviour of workplace by combining motivation and commitment theories (Meyer et al., 2004). Latterly, commitment scholars become more concerned with variables based on motivation. (Johnson et al., 2010) report that commitment is motivational phenomenon.The learning and growth opportunities increase organizational commitment level. To make employees satisfied and committed to jobs, there is need for strong and effective motivational strategies at certain organization levels. The following hypotheses used to show relationship between employee motivation and three faces of organizational commitment (affective, continuance \& normative commitment).

H1: There is positive relationship between employee's motivation and affective commitment.

$\boldsymbol{H 2}$ : There is positive relationship between employee's motivation and continuance commitment.

H3: There is positive relationship between employee's motivation and normative commitment.

\subsection{The Moderating Role of Power Distance}

Arguments by the authors of GLOBE-global leadership \& organizational behaviour effectiveness research program (House et al., 2004), that in low power distance culture, power sharing \& empowerment is more effective in the organization as compared high power distance culture. Regarding this, organizations having low or high values of power distance more readily affect employees' behaviour that relate to authority and order in decision-making. Past organizational culture research shows that organization members' interaction and approach to one another for problem solving is influence by the norms observed and organization values (O'Reilly \& Chatman, 1996).

In an organization power distance is considered as important factor of internal social conditions for shopping practices of management and amongst the most appropriate values for observing employment relationship role (Chen \&Aryee, 2004; Hui et al., 2004). In this study, power distance is examined as moderator on relationship among employee motivation and organization commitment. The power distance is degree of disparity exists among less powerful and more powerful person. Hofsted (2001) describe that power distance is the degree of power, which managers impose upon their subordinates. When there is a great degree of power on subordinate, it is considered as high power distance orientation whereas when there is small degree of power used it is known as low power distance orientation. It was stated that countries having high power distance in their organization, employees prefer closer attention, are more task oriented, superior-subordinate relationship and work hard as compared to less power distance countries (Bochner \& Hesketh, 1994). Thus, we proposed following hypothesis to examine power distance role in relationship among employees' motivation and organizational commitment faces (affective, continuance $\&$ normative commitment).

H4: Power distance moderates the relationship between employees' motivation and affective commitment, in the sense that relationship is stronger in lower power distance culture then higher power distance culture.

H5: Power distance moderates the relationship between employees' motivation and continuance commitment, in the sense that relationship is stronger in lower power distance culture then higher power distance culture.

H6: Power distance moderates the relationship between employee's motivation and normative commitment, in the sense that relationship is stronger in lower power distance culture then higher power distance culture.

\section{Methodology}

4.1 Population and Sample: The target population of this study includes total number of ten universities of Pakistan including public and private universities. 350 questionnaires were circulated to universities including both public and private universities located in different cities. Out of this total 300 respondents completed the questionnaire and the response rate for this study was $86 \%$.

4.2 Data Collection Method: Data was collected by following simple random sampling technique. Employee motivation was measured by 14 items scale used by (Ewen et al., 1966), Sergiovanni (1966), Graen (1966), (Lindsay et al., 1967), (House \& Wigdor ,1967), Maidani (1991), (Pizam \& Ellis ,1999), Affective, continuance and normative by 15 items scale 5 for each component used by (Meyer \& Allen, 1996:1).Power distance was measured by 6 items scale used by (Clugston, Dorfman \& Howell, 2000).

4.3 Statistical \& Data Analysis: Statistical analyses consists descriptive \& inferential statistics. Descriptive statistics in present study based on frequency tables to provide key demographic variables information. An inferential test used in current research includes Pearson correlation coefficient and Hierarchical Multiple Regression analysis .Pearson's correlation coefficient is use to test relationship between employee's motivation 
\& organizational commitment (affective, continuance \& normative commitment). Hierarchical multiple regression analysis is use to examine moderating role of power distance in the relationship between employee's motivation and organizational commitment (OC) components which includes affective, continuance and normative commitment.

\section{Results and discussion}

Demographic findings took place in initial stage of the research. Gender distributions of sample shows that $68 \%$ respondents are male, while remaining $32 \%$ are female. Age distribution of sample shows that $42 \%$ respondents are between the age of 30 and 35 years and less numbers are the age group of 51 and above that are $3 \%$. Marital status shows that $68 \%$ respondents are married and $32 \%$ are unmarried. Designationindicates that $58 \%$ of sample occupied Lecturer's position, while 34\% are Assistant professors, $4 \%$ are Associate professors and $4 \%$ are Professors.

$59 \%$ employees are working as a regular while remaining $41 \%$ are working on contract in the universities. 53\% are working on current job for less than 3 years, while $4 \%$ have their experience between 11 and 15 years. Higher percentage 48\% respondents are working in the university for less than 3 years whereas lower percentage respondents $6 \%$ are 16 years or above.

Fig5.1: Gender distribution of a sample

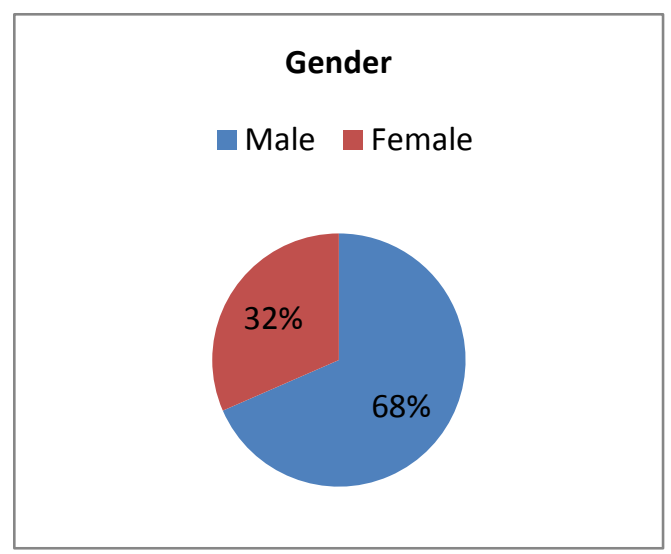

Fig5.3: Marital status of a sample

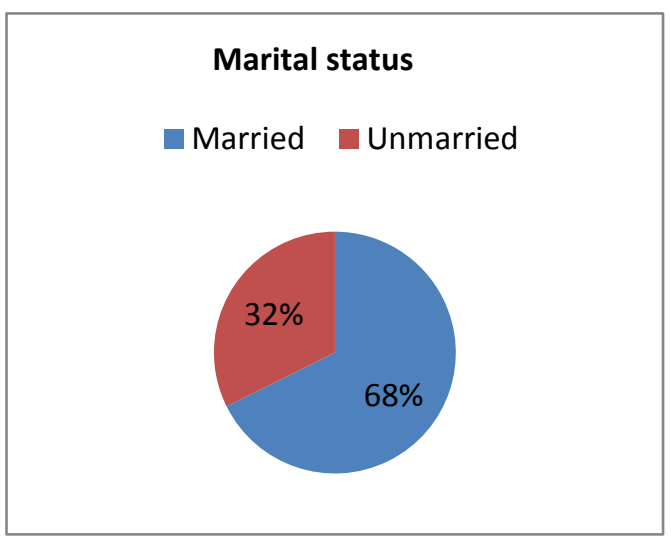

Fig5.2: Age distribution

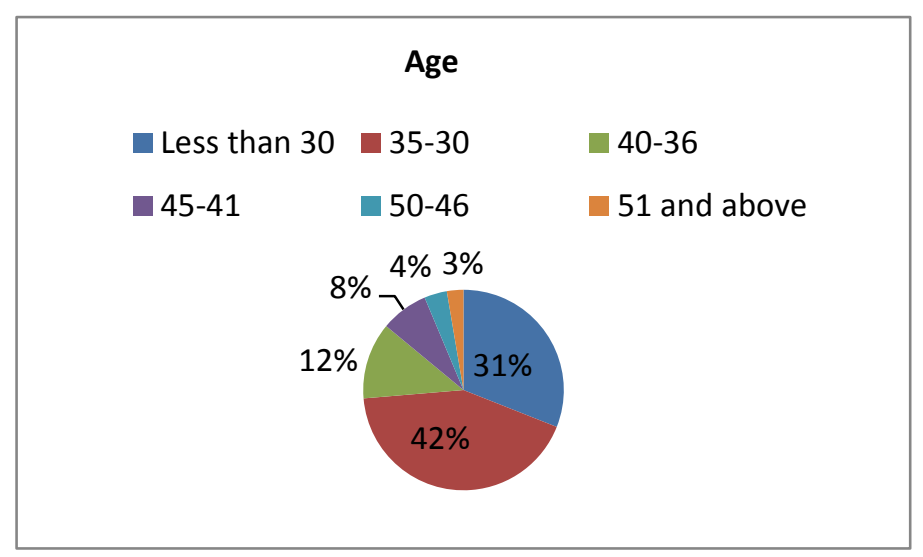

Fig5.4: Designations of a sample

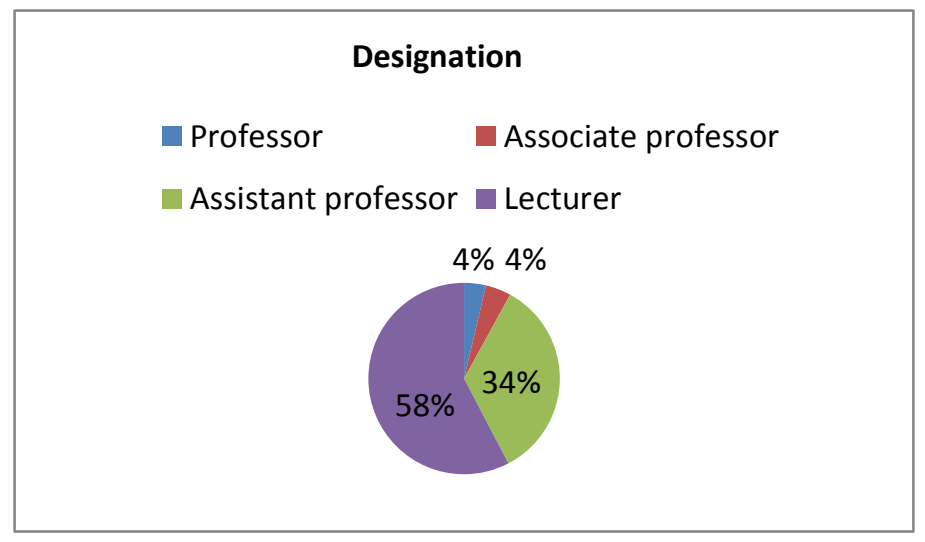


Fig 5.5: Nature of appointment

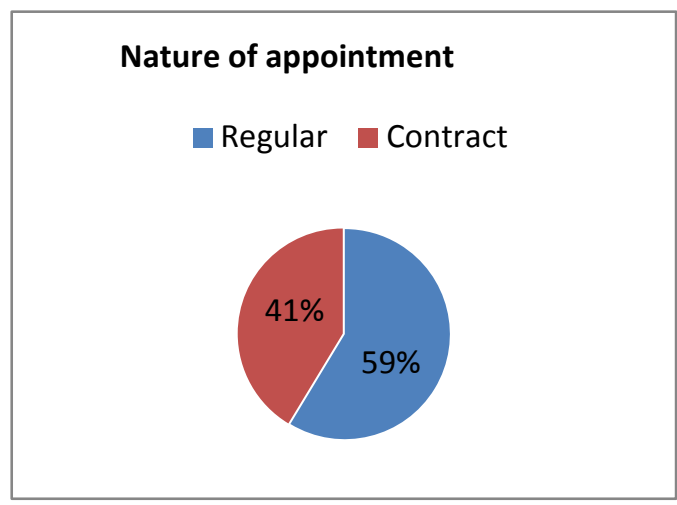

\section{Fig 5.6: Tenure at current job}

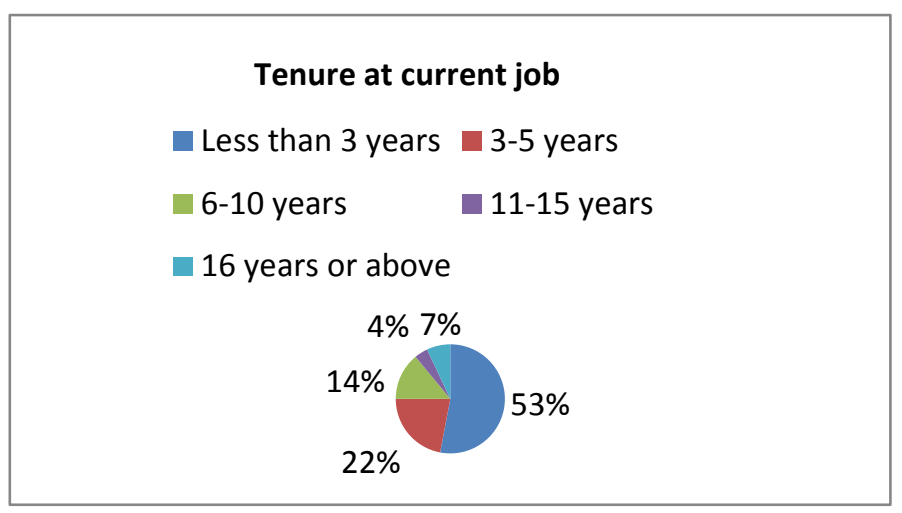

Fig 5.7: Tenure in the university

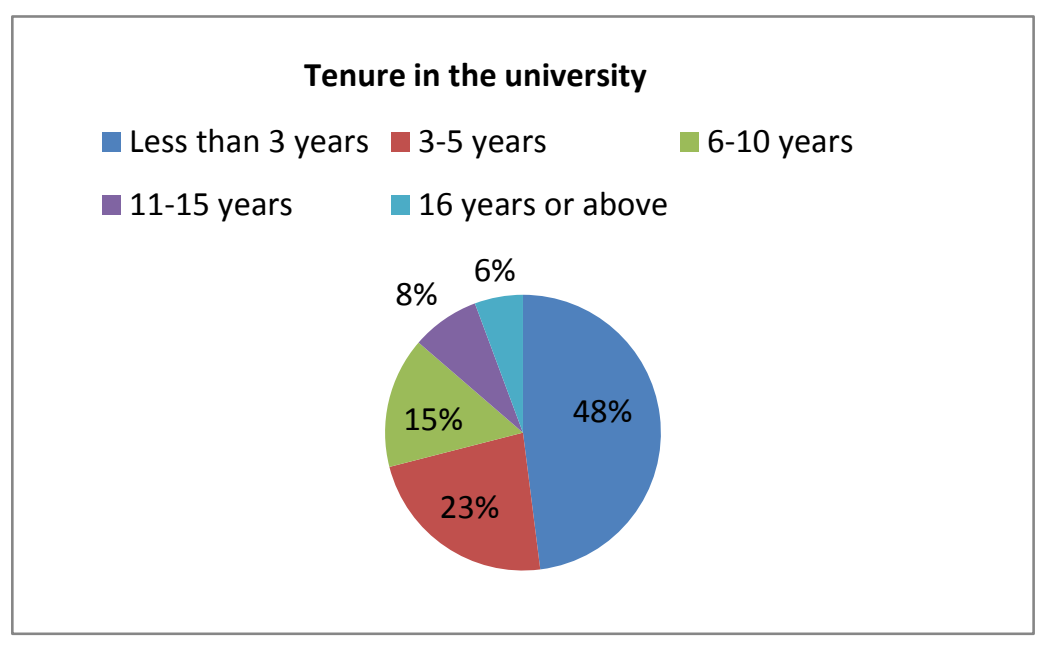

Table 5.1: Correlation between employee motivation and organizational commitment

\begin{tabular}{|l|l|l|}
\hline & \multicolumn{2}{|l|}{ Employee motivation } \\
\hline Variables & Pearson Correlation & Sig. (2-tailed) \\
\hline Affective commitment & $.540(* *)$ & .000 \\
\hline Normative commitment & $.336(* *)$ & .000 \\
\hline Continuance commitment & $.254(* *)$ & .000 \\
\hline
\end{tabular}

Correlation is significant at the 0.01 level (2-tailed).

To determine the relationship between employee motivation and organizational commitment. Pearson correlation test is used. Results in table 5.1 indicate that employee motivation positively correlates with affective commitment $(r=0.540, p<0.01)$. Results supports hypothesis $\mathrm{H}_{1}$ that there is positive relationship between employees' motivation and affective commitment. Correlation between employees' motivation and normative commitment $(\mathrm{r}=.336, \mathrm{p}<0.01)$ showing positive and supporting hypothesis $\mathrm{H}_{2}$ that there is positive relationship between employee motivation and normative commitment. Relationship between employees' motivation and continuance commitment $(\mathrm{r}=.254, \mathrm{p}<0.01)$ is positive which support hypothesis $\mathrm{H}_{3}$ indicating a positive relationship between employee's motivation and continuance commitment.

The results as depicted in Table 5.1 indicate a significant relationship between employee's motivation and affective commitment. Thus fulfilling our hypothesis $\mathrm{H}_{1}$ by rejecting null hypothesis and accepting alternative hypothesis. The relationship between employee's motivation and normative commitment show positive result. 
Here our hypothesis $\mathrm{H}_{2}$ is also true. Relationship between employees motivation and continuance commitment is positive. Our hypothesis $\mathrm{H}_{3}$ is also true.

Table 5.2: Model summary (Power distance role in the relationship between employee motivation \& affective commitment)

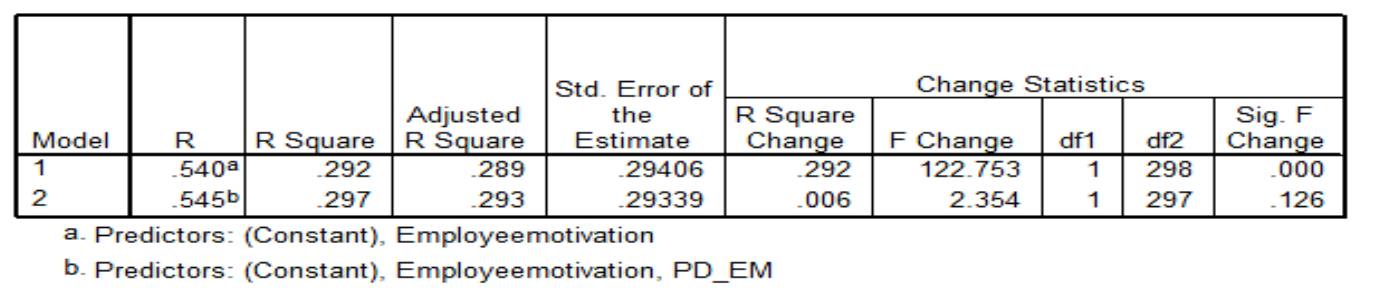

To determine power distance role in relationship between employees' motivation and organizational commitment (OC), hierarchical multiple regression analysis is use. The table 5.2 shows that when the variables entered in the model $1(\mathrm{EM} \& \mathrm{AC})$, it explains $29.2 \%$ of the variation. Similarly, when interaction term (PD_EM) a cross multiplication of power distance and employee motivation use in the model 2. It explains $29.7 \%$ of the variation. To find out overall variation we need to analyze $\mathrm{R}$ square change. The output presented in the model 2 shows that $\mathrm{R}$ square change value is 0.006 . It means that interaction term explains an additional $0.6 \%$ of variation or we can say that power distance enhance relationship between employee's motivation and affective commitment by $0.6 \%$.

Table 5.3: ANOVA (Power distance role in the relationship between employee's motivation \& affective commitment)

\begin{tabular}{|ll|r|r|r|r|r|}
\hline Model & & \multicolumn{1}{c|}{$\begin{array}{c}\text { Sum of } \\
\text { Squares }\end{array}$} & df & Mean Square & \multicolumn{1}{c|}{$\mathrm{F}$} & Sig. \\
\hline 1 & Regression & 10.614 & 1 & 10.614 & 122.753 & $.000^{\mathrm{a}}$ \\
& Residual & 25.768 & 298 & .086 & & \\
& Total & 36.382 & 299 & & & $.000^{\mathrm{b}}$ \\
& Regression & 10.817 & 2 & 5.408 & 62.833 & \\
& Residual & 25.565 & 297 & .086 & & \\
& Total & 36.382 & 299 & & & \\
\end{tabular}

\footnotetext{
a. Predictors: (Const ant), Employ eemotiv ation

b. Predictors: (Constant), Employ eemotivation, PD_EM

c. Dependent Variable: Af fectiv ecommitment
}

The ANOVA table 5.3 indicates that model as a whole, (which includes both models) is significant, where model 1 is significant without interaction term.

Model 2 is significant with interaction term.

$$
F(1,298)=122.753, \mathrm{p}<0.01
$$

$$
F(2,297)=62.833, \mathrm{p}<0.01 \text {. }
$$

The results presented in the above tables indicate that power distance moderates relationship between employees' motivation and affective commitment. Thus it supports our hypothesis $\mathrm{H}_{4}$. So we accept alternative hypothesis and reject our null hypothesis.

Table 5.4: Model Summary (Power distance role in the relationship between employees' motivation and normative commitment)

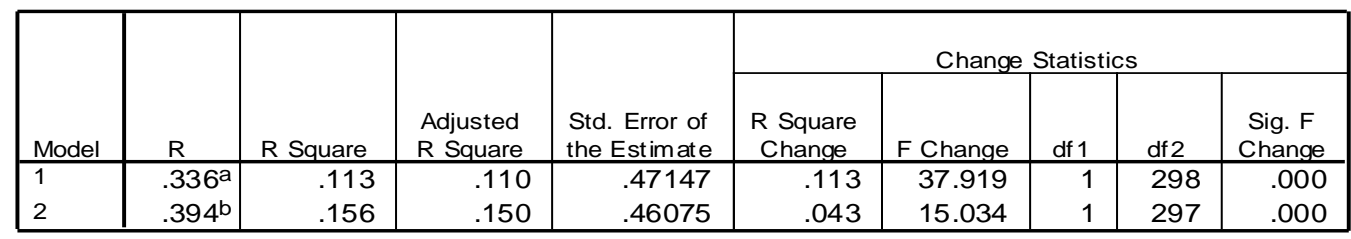

a. Predictors: (Constant), Em ploy eemotiv ation

b. Predictors: (Constant), Em ploy eemotiv ation, PD_EM

The results presented in the model summary table 5.4 indicate that when variables (Employee motivation \& normative commitment) enter in the model 1 it shows $11.3 \%$ of the variation. Similarly when interaction term has been included in the model 2 it gives $15.6 \%$ of the variation as a whole. 
For overall variation see in the $\mathrm{R}$ square change column. The $\mathrm{R}$ square change value presented in the model 2 is 0.043 . It shows that power distance moderates relationship between employee's motivation and normative commitment by $4.3 \%$ or interaction term explains an additional $4.3 \%$ of variation.

Table 5.5: ANOVA (Power distance role in the relationship between employees' motivation and normative commitment)

\begin{tabular}{|c|c|c|c|c|c|c|}
\hline Model & & $\begin{array}{l}\text { Sum of } \\
\text { Squares }\end{array}$ & df & Mean Square & $\mathrm{F}$ & Sig. \\
\hline 1 & $\begin{array}{l}\text { Regression } \\
\text { Residual } \\
\text { Total }\end{array}$ & $\begin{array}{r}8.429 \\
66.241 \\
74.670\end{array}$ & $\begin{array}{r}1 \\
298 \\
299\end{array}$ & $\begin{array}{r}8.429 \\
.222\end{array}$ & 37.919 & $.000^{a}$ \\
\hline 2 & $\begin{array}{l}\text { Regression } \\
\text { Residual } \\
\text { Total }\end{array}$ & $\begin{array}{l}11.620 \\
63.049 \\
74.670\end{array}$ & $\begin{array}{r}2 \\
297 \\
299\end{array}$ & $\begin{array}{r}5.810 \\
.212\end{array}$ & 27.369 & $.000^{b}$ \\
\hline
\end{tabular}
a. Predictors: (Const ant), Employ eemotiv ation
b. Predictors: (Const ant), Employ eemotiv ation, PD_EM
c. Dependent Variable: Normativecommitment

The ANOVA table 5.5 explains that model as a whole, (which includes both models) is significant, where model 1 is significant without interaction term.

Model 2 is significant with interaction term.

$$
F(1,298)=37.919, \mathrm{p}<0.01
$$

$$
F(2,297)=27.369, \mathrm{p}<0.01 \text {. }
$$

As the results presented in the above tables indicates that power distance moderates or enhance relationship between employee's motivation and normative commitment, thus accepting our alternative hypothesis.

Table 5.6: Model Summary (Power distance role in the relationship between employees' motivation and continuance commitment)

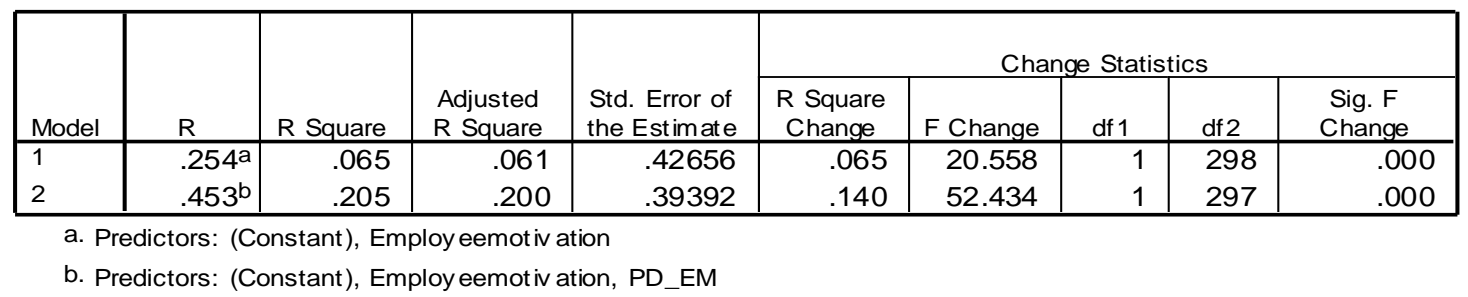

Results presented in table 5.6 explain that when variables (Employee motivation \& continuance commitment) enter in the model 1 it shows $6.5 \%$ of the variation. Similarly when interaction term also included in the model 2 it gives $20.5 \%$ of the variation as a whole.

In the table $\mathrm{R}$ square change column shows overall variation. The $\mathrm{R}$ square change value presented in the model 2 is 0.140 , which shows that power distance moderate relationship between employees' motivation, and continuance commitment by $14 \%$ or interaction term explains an additional $14 \%$ of variation.

Table 5.7: ANOVA (Power distance role in the relationship between employees' motivation and continuance commitment)

\begin{tabular}{|ll|r|r|r|r|r|}
\hline Model & & \multicolumn{1}{c|}{$\begin{array}{c}\text { Sum of } \\
\text { Squares }\end{array}$} & df & Mean Square & F & Sig. \\
\hline 1 & Regression & 3.741 & 1 & 3.741 & 20.558 & $.000^{\mathrm{a}}$ \\
& Residual & 54.223 & 298 & .182 & & \\
& Total & 57.963 & 299 & & & $.000^{\mathrm{b}}$ \\
\hline 2 & Regression & 11.877 & 2 & 5.938 & 38.270 & \\
& Residual & 46.086 & 297 & .155 & & \\
& Total & 57.963 & 299 & & & \\
\end{tabular}

a. Predictors: (Const ant), Employ eemotivation

b. Predictors: (Constant), Employ eemotivation, PD_EM

c. Dependent Variable: Continuancecommitment 
The ANOVA table 5.7 indicates that model as a whole, (which includes both models) is significant.

$$
F(2,297)=38.270, \mathrm{p}<0.01
$$

As the results presented in the above table shows that power distance moderates relationship between employee's motivation and continuance commitment, so here we reject null hypothesis and accept alternative hypothesis.

\section{Conclusion}

The current study helps to understand relationship between employees' motivation and organizational commitment, and furthermore it explains the moderating role of power distance in the relationship between employee's motivation and organizational commitment in universities of Pakistan. As hypothesized, the relationship between employee motivation and organizational commitment components (affective, continuance and normative commitment) is moderated by power distance.

The relationship between employees motivation and affective commitment (AC) is positive, which shows that the more employees are motivated the more emotional attachment to universities by them. If employees are not motivated, their commitment level might decline and they will quit as soon as possible. If an employer wants employees to stay in that institute they have to motivate them in their work. Similarly the relationship between employee's motivation and normative commitment (NC) is positive. When employees are motivated then they feel to stay in the university instead of moving from one university to another because it seems unethical and its moral obligation to remain in that university where they are working. Relationship between employee's motivation \& continuance commitment (CC) is also positive. When motivation level for employees is high they prefer to stay instead of leaving because they feel that it is costly for them to leave the universities.

Results regarding power distance role revealed that power distance moderates relationship between employee's motivation \& affective commitment $(\mathrm{AC})$ in the sense that relationship is stronger in low power distance culture then high power distance culture. Culture having low power distance, their management decision style is democratic. Employees and subordinates are equal. They share every type of problem with each other and have friendly environment. Where as in high power distance culture management style is autocratic. Leaders and subordinates are not equal \& close. Power distance also moderates relationship between employee's motivation \& normative commitment (NC) in the sense that relationship is stronger in low power distance culture then high power distance culture. Finally Power distance moderates relationship between employee's motivation \& continuance commitment (CC) in the sense that there is stronger relationship in low power distance culture as compare to culture with high power distance.

\section{References}

[1]. Allen, N. J., \& Meyer, J. P. (1990). The measurement and antecedents of affective, continuance and normative commitment to the organization. Journal of occupational psychology, 63(1), 1-18.

[2]. Anderfuhren-Biget, S., Varone, F., Giauque, D., \& Ritz, A. (2010). Motivating employees of the public sector: Does public service motivation matter? International public management journal, 13(3), 213-246.

[3]. Białas, S. (2009). Power distance as a determinant of relations between managers and employees in the enterprises with foreign capital.Journal of Intercultural Management, 1(2), 105-115.

[4]. Bochner, S., \&Hesketh, B. (1994). Power distance, individualism/collectivism, and job related attitudes in a culturally diverse work group. Journal of Cross-Cultural Psychology, 25(2), 233-257.

[5]. Chen, Z. X., \&Aryee, S. 2004. Empowered to act: understanding the relationship between delegation and employee outcomes in China. Academy of Management Best Paper Proceedings '2004, Louisiana, USA, OB: H1-6. (Carolyn Dexter Award Nominee).

[6]. Clugston, M., Howell, J. P., \&Dorfman, P. W. (2000). Does cultural socialization predict multiple bases and foci of commitment? Journal of management, 26(1), 5-30.

[7]. De Silva, D., \&Yamao, M. (2004). The involvement of female labor in seafood processing in Sri Lanka: impact of organizational fairness and supervisor evaluation on employee commitment. Paper presented at the Global Symposium on Gender and Fisheries: Seventh Asian Fisheries Forum

[8]. Eby, L. T., Freeman, D. M., Rush, M. C., \& Lance, C. E. (1999). Motivational bases of affective organizational commitment: A partial test of an integrative theoretical model. Journal of Occupational and Organizational Psychology, 72(4), 463-483.

[9]. Ewen, R. B., Smith, P. C., \&Hulin, C. L. (1966).An empirical test of the Herzberg two-factor theory. Journal of Applied Psychology, 50(6), 544

[10]. Greenberg, J., \& Baron, R. A., (2003), Behavior in Organizations (8th edition). Upper Saddle River, New Jersey: Prentice Hall 2.

[11]. Hennessey, B., \&Amabile, T. (2005).Extrinsic and intrinsic motivation. The Blackwell Encyclopedia of Management: Blackwell Publishing.

[12]. House, R. J., \&Wigdor, L. A. (1967). Herzberg's dual factor theory of job satisfaction and motivation: a review of the evidence and a criticism. Personnel Psychology, 20(4), 369-390

[13]. House, R. J., Hanges, P. J., Javidan, M., Dorfman, P. W., \& Gupta, V. (2004). Leadership, culture, and organizations: The GLOBE study of 62 societies. Beverly Hills: Sage Publications.

[14]. Hui, C., Lee, C., \& Rousseau, D. M. (2004). Psychological contract and organizational citizenship behavior in China: investigating generalizability and instrumentality. Journal of Applied Psychology, 89(2), 311 
[15]. Kim, W. G., Leong, J. K., \& Lee, Y.-K.(2005). Effect of service orientation on job satisfaction, organizational commitment, and intention of leaving in a casual dining chain restaurant.International Journal of Hospitality Management, 24(2), 171-193

[16]. Kinicki, A., \&Kreitner, R. (2003). Organizational behavior: key concepts, skills \& best practices: McGraw-Hill/Irwin

[17]. Lather, S., \& Jain, S. (2005). Motivation and job satisfaction a study of associates of public and private sector. Delhi Business Review, 6(1), 77-84.

[18]. Lindenberg, S. (2001).Intrinsic motivation in a new light.Kyklos, 54(2), 317-342

[19]. Lindsay, C. A., Marks, E., \&Gorlow, L. (1967). The Herzberg Theory: a critique and reformulation.

[20]. Maidani, E. A. (1991). Comparative study of Herzberg's Two-Factor Theory of job satisfaction among public and private sectors.Public Personnel Management.

[21]. McCabe, T. J., \&Garavan, T. N. (2008). A study of the drivers of commitment amongst nurses: The salience of training, development and career issues. Journal of European Industrial Training, 32(7), 528-568.

[22]. Meyer, J. P., \& Allen, N. J. (1991).A three-component conceptualization of organizational commitment.Human resource management review, 1(1), 61-89.

[23]. Meyer, J. P., \& Allen, N. J. (1997). Commitment in the workplace: Theory, research, and application: Sage.

[24]. Meyer, J. P., Becker, T. E., \&Vandenberghe, C. (2004). Employee commitment and motivation: a conceptual analysis and integrative model. Journal of Applied Psychology, 89(6), 991.

[25]. Mitchell, T. R. (1982). Motivation: New directions for theory, research, and practice. Academy of management review, 7(1), 80-88.

[26]. Mowday, R. T., Steers, R. M., \& Porter, L. W. (1979). The measurement of organizational commitment.Journal of vocational behavior, 14(2), 224-247.

[27]. Opkara, J. O. (2004). Job satisfaction and organizational commitment: Are there differences between American and Nigerian managers employed in the US MNCs in Nigeria. Academy of Business \& Administrative Sciences, Briarcliffe College, Switzerland.

[28]. Pierce, C. A., \&Aguinis, H. (2003). Romantic relationships in organizations: A test of a model of formation and impact factors. Management Research: The Journal of the Iberoamerican Academy of Management, 1(2), 161-169.

[29]. Rainey, H. G. (1993). Work motivation. In R.T. Golembiewski (Ed.), Handbook of Organizational Behavior (pp. 19-39). New York: Marcel Dekker

[30]. Ramlall, S. (2004).A review of employee motivation theories and their implications for employee retention within organizations.Journal of American Academy of Business, 5(1/2), 52-63.

[31]. Rayton, B. A. (2006). Examining the interconnection of job satisfaction and organizational commitment: an application of the bivariate probit model.The International Journal of Human Resource Management, 17(1), 139-154.

[32]. Rodrigues, C. A. (1998). Cultural classifications of societies and how they affect cross-cultural management. Cross Cultural Management: An International Journal, 5(3), 31-41.

[33]. Ryan, R. M., \&Deci, E. L. (2000). Intrinsic and extrinsic motivations: Classic definitions and new directions. Contemporary educational psychology, 25(1), 54-67.

[34]. Sergiovanni, T. J. (1966). Investigation of factors which affect job satisfaction and job dissatisfaction of teachers.University of Rochester.College of Education.

[35]. Shami, P. (1999). Higher Education in Pakistan: A cause for change from Higher Education Commission Review.

[36]. Shane, S. (1994). The effect of national culture on the choice between licensing and direct foreign investment. Strategic Management Journal, 15(8), 627-642.

[37]. Smith, G. P. (1994). Motivation. In W. Tracey (ed.), Human resources management and development handbook (2nd ed.).

[38]. Snell, S. (1998). Motivate Your Staff: Kogan Page Limited

[39]. Thomas, K. W. (2000). Intrinsic motivation at work: Building energy \& commitment: Berrett-Koehler Pub

[40]. Torrington, D. Hall. L. \& Taylor, S.(2002). Human Resource Management.Prentice-Hall, London.

[41]. Warsi, S., Fatima, N., \&Sahibzada, S. A. (2009). Study on relationship between organizational commitment and its determinants among private sector employees of Pakistan. International Review of Business Research Papers, 5(3), 399-410. 